\title{
KVAPŲ TAIKYMO GALIMYBĖS KURIANT ORGANIZACIJOS İVAIZDI
}

\author{
Diana Barragan Ferrer, Žaneta Mickienė, Ilona Kupčikienė, Sigita Zlatkuvienė, \\ Gerda Matelienė, Augustina Rudžionienė, Agnẻ Šidagienė \\ Kauno kolegijos Medicinos fakultetas
}

\author{
Raktažodžiai: organizacijos įvaizdis, pojūčių marke- \\ tingas.
}

\begin{abstract}
Santrauka
Šiandieninès konkurencijos akivaizdoje organizacijos ivvaizdis tapo ypač svarbia konkurencinio pranašumo igijimo ir efektyvios veiklos vystymo priemone. Nors esama labai daug komunikacijos kanalų ir būdų, tačiau klientą pasiekti tenka vis sudètingiau. Daugelis organizacijų stiprindamos savo ịvaizdị vis dažniau pasitelkia sensorinę rinkodarą - komunikavimą per klientų pojūčius, dar kitaip vadinamą pojūčių marketingu. Mokslinejje literatūroje teigiama, jog pozityvias emocijas galima sužadinti tinkamai paveikiant visus penkis žmogaus pojūčius. Pojūčių marketingas padeda užmegzti emocinius ryšius su klientais, sukuria ilgalaikị lojalumą organizacijai.

Tyrimo tikslas - atskleisti kvapų taikymo galimybes kuriant organizacijos ịvaizdį. Kiekybinio tyrimo rezultatai atskleidè, kad, daugumos respondentų manymu, reprezentacinis kvapas yra „svarbus“ kuriant organizacijos įvaizdį. Organizacijos įvaizdžio kūrimui respondentai rinktųsi gaivius su citrusinių vaisių natomis, švelnius, subtilius arba neženkliai juntamus kvapus. Tyrimo rezultatai parodè, kad Kauno kolegijos veiklos bruožai: atsakomybè ir profesionalumas respondentams asocijuojasi su medienos kvapu, atvirumas ir pagarba su gèlių aromatu, o su bendruomeniškumu respondentams asocijuojasi žalumos ir citrusų kvapai. Respondentų manymu, tinkami ịvairūs organizaciją reprezentuojantys kvapų panaudojimo būdai: aromatinès žvakès, aromatizatoriai ir aromatinès lazdelès.
\end{abstract}

\section{Ivadas}

Gyvenimo pokyčiai organizacijoms kelia vis naujus iššūkius ne tik išsiskirti, turèti pranašumą, bet ir būti patikimomis, turèti gerą reputaciją. Šiandien organizacijos sèkmè vis labiau siejama su jos gebejjimu kurti ir valdyti savo išteklius, vienas kurių ir yra organizacijos įvaizdis. Teigiamas organizacijos iqvaizdis neatsiranda savaime, jis sukuriamas, pasiekiamas, o kartu ir valdomas. Tikslingai formuoti ịvaizdį nèra lengvas procesas, todèl aktualu žinoti ne tik ịvaizdžio klasifikacijos sampratą, bet ir jo formavimo svarbiausias ypatybes bei pagrindines dedamąsias.

Metodų, kuriais remiantis organizacija galètų susikurti tinkamą ịvaizdị, mokslinèje literatūroje yra pateikta nemažai, joje aprašomi ịvairūs ịvaizdžio formavimo ir valdymo modeliai. Tiek užsienio šalių, tiek lietuvių autoriai kuria ir tobulina įvaizdžio kūrimo modelius, tyrinejja organizacijų įvaizdžio formavimo klausimus įvairiais aspektais.

R.Baltušienè apibūdina organizacijos įvaizdị kaip ,,būtinybę organizacijai, norinčiai pasiekti ilgalaikę sèkmę, padedančią pritraukti naujus klientus ir partnerius, skatinančią organizacijos dinamišką plètrą“" [1]. Organizacijos ịvaizdžio kūrimas yra vienas iš strateginio valdymo ir marketingo tikslų. Tai ne mažiau svarbu, negu naujų technologijų diegimas, personalo ugdymas bei kita. Kiekvienos organizacijos formuojamo ịvaizdžio tikslai atspindi ịsipareigojamą kokybę, kompetenciją ir organizacijos santykius su aplinka [2]. Ivvaizdis skirstomas $\underset{i}{i}$ vidinị ir išorinị: vidinis - išreiškiamas organizacijos vidinejje aplinkoje, išorinis - už jos ribų. Kaip teigia A.Mikelionytė, ,tiek išorinis, tiek vidinis įvaizdis yra svarbūs, nes garantuoja sèkmingą organizacijos veiklą. Vidinis įvaizdis stiprina darbuotojų motyvaciją, skatina darbo našumą, o išorinis įvaizdis padeda išlaikyti ir pritraukti nauju klientų bei kompetentingų darbuotojų demesic" [3]. A.Krishna teigimu, siekiant plètoti ar vystyti pojūčiais sustiprintą ịvaizdi reikètų išskirti, jog iš išorès ateinantys stimulai, kurie identifikuojami akimis, ausimis ir kitais jutimo organais, smegenyse atkoduojami ir interpretuojami per gebejjimą pažinti ir patiriamas emocijas [4]. Stimulų veikiamos emocijos gali kelti prisiminimus ar skatinti vaizduotę. Tarkim kvapai, kurie primena išgyventus potyrius, kurie greičiausiai žadina emocinius prisiminimus, o ne loginę atmintị [5].

Kvapai pirmiausia žadina atmintį - ne loginę, o emocinę. Todèl visi kvapai priimami su emociniu atspalviu, jie mums patinka ar ne - ,,abejingų“ kvapams nèra. Tam, kad suvok- 
tume bei apibrèžtume kvapą, būtina jị apibūdinti suteikiant apibrèžimą. Lietuvos teisinèje bazèje Higienos norma - HN 121:2010 „Kvapo koncentracijos ribinè verté gyvenamosios aplinkos ore" reglamentuojama ir apibrèžiama kvapų sąvoka. Kvapas - tai organoleptinè savybè, kurią junta uoslès organas, ikvepiant tam tikrų lakiųjų medžiagų [6]. Žinoma, kad kvapo fizines savybes žmogus užuodžia nosyje esančiomis nervinèmis ląstelèmis, o suvokia smegenimis. „Kvapo poveikio mechanizmas yra skirstomas ị specifinị ir nespecifinį. Specifinis kvapo mechanizmas suprantamas, kai lakios kvapnios medžiagos sudirgina nosies uoslès epitelio receptorius. Nespecifinis kvapo mechanizmas, tai psichoemocinis asociatyvusis, kai kvapas asocijuojasi su ankstesne patirtimi. Būtent šio mechanizmo ypatybè yra ta, kad žmogus gali užuosti menkiausios koncentracijos kvapniają medžiagą [7].

M.Lindstrom teigimu, natūralūs ir dirbtiniai aromatai šiandien naudojami ne tik parfumerijoje, kosmetikoje, buitineje chemijoje ir maisto pramoneje. Randamos vis naujos kvapų pritaikymo galimybès [8]. Aromatizuojama vis daugiau prekiu - nuo drabužių iki automobilių. Atsirado nemažai aromatizuotų suvenyrų, logotipų, kvapus reklamuojančių ịdėklų žurnaluose ir kt. Specialiai parinktais kvapais kvepinamos ịvairios patalpos: prekybinès - siekiant padidinti pardavimus, biuro - pakelti darbo našumui, visuomeninès - norint sumažinti agresiją ir pan. Kvapas yra puiki priemonè atkreipti dèmesí, perduoti žinutę. Jis vilioja, paịvairina, skatina domètis, sukelia senas asociacijas ir sukuria naujas.

Vieninga kvapo komunikacija užtikrina, kad organizacija turès savo identitetą, kurị lengvai ịsimins vartotojai. Toks pats kvapas, naudojamas skirtingais būdais, gerina prekès ženklo įvaizdị, didina šansus būti pastebètam ir išskirtam iš konkurentų.

Tada, kai žmogus mato, girdi, ragauja, liečia - jis gauna informaciją. Tada, kai užuodžia - staigiai yra pasiekiami jausmai ar atmintis. Kvapo informacija saugoma atmintyje ir turi stiprius ryšius su emocine atmintimi [9].

Pasak M.Maymand ir kt., pagrindinė pojūčių marketingo užduotis vartotojų atžvilgiu - pagerinti pirkejjų nuotaiką pirkimo metu [9]. Dauguma pirkẻjų nori ir laukia teigiamų emocijų bei malonių pojūčių. Kaip teigia autorius, pojūčių marketingo pagrindiniai teoriniai sprendimai turi remtis žmogaus jutimo organų poveikio pažinimu, t. y. kokias asociacijas sukelia tam tikrai tikslinei auditorijai spalva, garsas, forma, skonis, kvapas ir kiti identiteto elementai, kurie kuria bendrą ịvaizdị ir pateikia pojūčių marketingo suformuotą îvaizdžio modelị $[5,9]$. Kaip teigia C.Spence, kvapas - vienas iš penkių pojūčių, labiausiai linkęs būti susietu su nuotaikos, emociniu, jausminiu poveikiu elgesiui. Kvapai keliauja tiesiai ị smegenis nusinešdami ten ir tam tikrą informaciją. Sąmoningai to kontroliuoti negalime, ịvertinus faktą, kad senoji (pirmykštè) ir limbinè smegenų sistemos pirmosios identifikuoja kvapus susiedamos juos su emocijomis [10].

Tyrimo tikslas - atskleisti kvapu taikymo galimybes kuriant organizacijos įvaizdị.

\section{Tyrimo objektas ir metodika}

Kiekybiniam tyrimui atlikti buvo vykdoma anketinè apklausa raštu. Kauno kolegijos bendruomenès nariai atrinkti netikimybinès patogiosios tikslinès atrankos būdu. Siekiant surinkti pirminius

1 lentelè. Anketos struktūrinès dalys.

\begin{tabular}{|c|c|c|}
\hline $\begin{array}{l}\text { Klausimų } \\
\text { blokas }\end{array}$ & Klausimas & Tikslas \\
\hline $\begin{array}{l}\text { Demografiniai } \\
\text { duomenys }\end{array}$ & $\begin{array}{l}\text { 1. Jūsų lytis? } \\
\text { 2. Jūsų pareigybè organizacijoje? }\end{array}$ & $\begin{array}{l}\text { Išsiaiškinti res- } \\
\text { pondentų ben- } \\
\text { druosius duo- } \\
\text { menis. }\end{array}$ \\
\hline $\begin{array}{l}\text { Respondentų } \\
\text { nuomonè apie } \\
\text { kvapų svarbą } \\
\text { kuriant organiza- } \\
\text { cijos įvaizdị }\end{array}$ & $\begin{array}{l}\text { 1. Kaip manote, ar kvapu panaudo- } \\
\text { jimas yra svarbus kuriant organiza- } \\
\text { cijos įvaizdį? } \\
\text { 2. Kaip manote, kuo kvapų panau- } \\
\text { dojimas svarbus kuriant organiza- } \\
\text { cijos įvaizdį? }\end{array}$ & $\begin{array}{l}\text { Išsiaiškinti nuo- } \\
\text { monę apie kvapų } \\
\text { svarbą kuriant } \\
\text { organizacijos } \\
\text { ịvaizdị. }\end{array}$ \\
\hline $\begin{array}{l}\text { Respondentų } \\
\text { nuomonė apie } \\
\text { kvapų tinka- } \\
\text { mumą, kuriant } \\
\text { reprezentacinį } \\
\text { Kauno kolegijos } \\
\text { kvapą }\end{array}$ & $\begin{array}{l}\text { 1. Pažymėkite, kaip Jūs ịsivaizduo- } \\
\text { jate Kauno kolegijos kaip organiza- } \\
\text { cijos reprezentacinį kvapą? } \\
\text { 2. Pažymėkite, kaip Jūs įsivaiz- } \\
\text { duojate Kauno kolegijos kaip or- } \\
\text { ganizacijos reprezentacinio kvapo } \\
\text { intensyvumą? } \\
\text { 3. Pasirinkite, kokios asociacijos } \\
\text { susijusios su kvapais Jums kyla } \\
\text { mąstant apie Kauno kolegijos vei- } \\
\text { klos bruožus. } \\
\text { 4. Pažymėkite, kurie iš išvardintų } \\
\text { kvapų tinkami kuriant reprezenta- } \\
\text { cinị kolegijos kvapą? }\end{array}$ & $\begin{array}{l}\text { Išsiaiškinti nuo- } \\
\text { monę apie kvapų } \\
\text { ti n k a m u m ą, } \\
\text { kuriant repre- } \\
\text { zentacinį Kauno } \\
\text { kolegijos kvapą. }\end{array}$ \\
\hline $\begin{array}{l}\text { Respondentų } \\
\text { mėgstamiausias } \\
\text { kvapas }\end{array}$ & $\begin{array}{l}\text { 1.Koks jūsų mėgstamiausias kva- } \\
\text { pas? }\end{array}$ & $\begin{array}{l}\text { I šs i a i š ki n t i } \\
\text { mègstamiausią } \\
\text { kvapą. }\end{array}$ \\
\hline $\begin{array}{l}\text { Kvapų panaudo- } \\
\text { jimo būdai }\end{array}$ & $\begin{array}{l}\text { 1. Pažymėkite, kurie iš išvardintų } \\
\text { kvapų panaudojimo būdų, Jūsų } \\
\text { manymu, tinkami kuriant organi- } \\
\text { zacijos įvaizdį? }\end{array}$ & $\begin{array}{l}\text { I šs i a i š ki n t i } \\
\text { kvapur panaudo- } \\
\text { jimo būdus. }\end{array}$ \\
\hline
\end{tabular}


duomenis, 2017 metų gruodžio ménesị buvo atlikta anoniminè apklausa raštu Kauno kolegijoje. Buvo apklausti 342 Kauno kolegijos bendruomenès nariai: studentai, desstytojai, administracijos darbuotojai. Visos anketos buvo išdalintos atsitiktinai sutiktiems Kauno kolegijos studentams, dèstytojams bei administracijai. Prieš sudarant anketą buvo susipažinta su Kauno kolegijos vizija, misija bei veiklos pobūdį apibūdinančiomis vertybèmis (pagal Kauno kolegijos internetinio puslapio informaciją):

- Atsakomybe் - mums yra sąžiningas, skaidrus sprendimų prièmimas ir igyvendinimas, atsižvelgiant ị studentų, dėstytojų, tẻvų, socialinių partnerių, darbdavių ir kitų visuomenès narių reikmes. Atsakomybè - tai įsipareigojimų, duotuc sau ir kitiems, ịvykdymas, racionaliai panaudojant turimus išteklius.

- Profesionalumas - mums yra pažinimas, prasidedantis nuo savęs, tikejjimas savo ir kitų jègomis, būtinybe kokybiškai ịgyvendinti sumanymus. Profesionalumą skatina nuolatinis žinių troškimas, asmens ir aplinkos savitarpio dermè, noras pasiekti tikslus, siekis lyderiauti savo srityje.

- Atvirumas - mums padeda atrasti, priimti, taikyti ir kurti naujoves bei žengti i priekị kartu su dinamišku veiklos pasauliu. Atsivèrimas - mūsų poreikis ir varomoji jèga, skatinantys dalintis patirtimi, tobuletti ir valdyti pokyčius. Tik laisvoje ir demokratiškoje aukštojoje mokykloje auga savarankiškai mąstančios ir kūrybingos asmenybès.

- $\quad$ Pagarba - mums yra tolerancija žmogui, nepriklausomai nuo amžiaus, lyties, rasès, požiūrio ir įsitikinimų. Pagarba kiekvieno darbui ir indèliui ị bendrą veiklą pa-

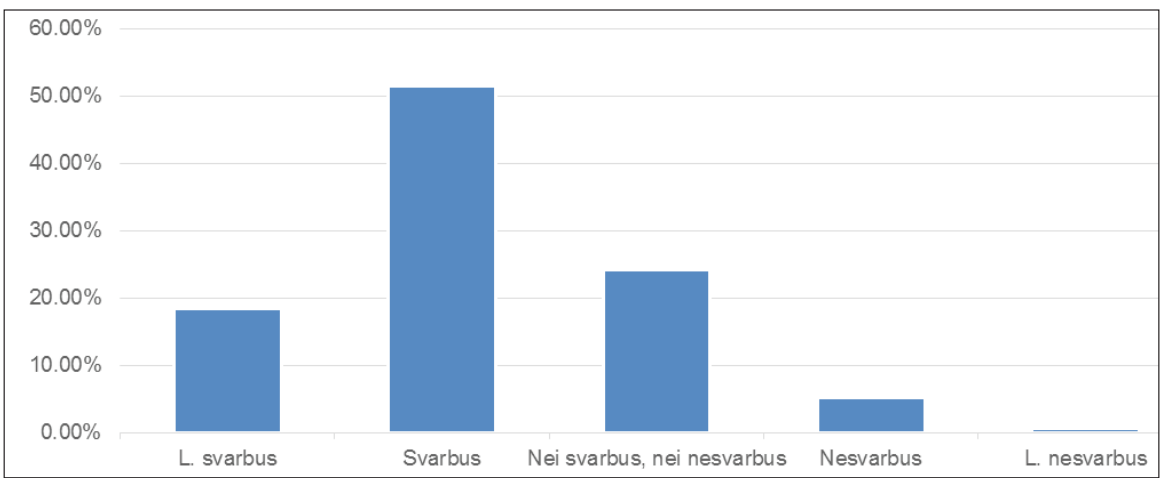

1 pav. Respondentų atsakymų pasiskirstymas pagal kvapų panaudojimo svarbą $(\mathrm{N}=342)$. Atsakymų dalis proc.

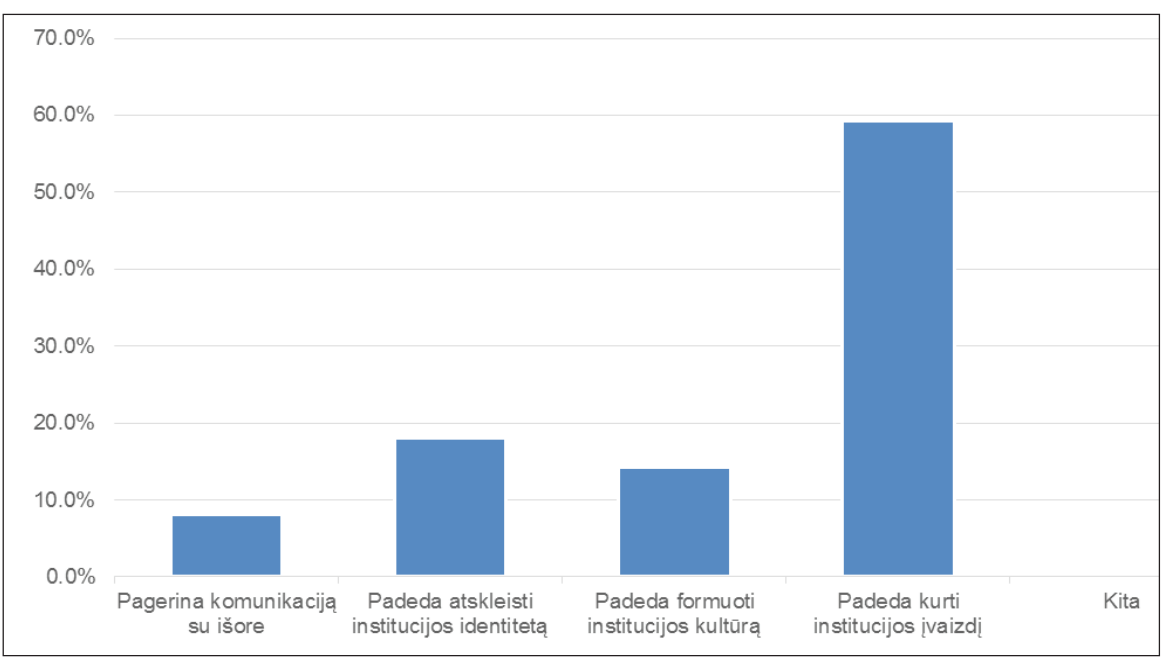

2 pav. Respondentų atsakymų pasiskirstymas pagal nuomonę dẻl kvapų panaudojimo paskirties $(\mathrm{N}=322)$. Atsakymų dalis proc.

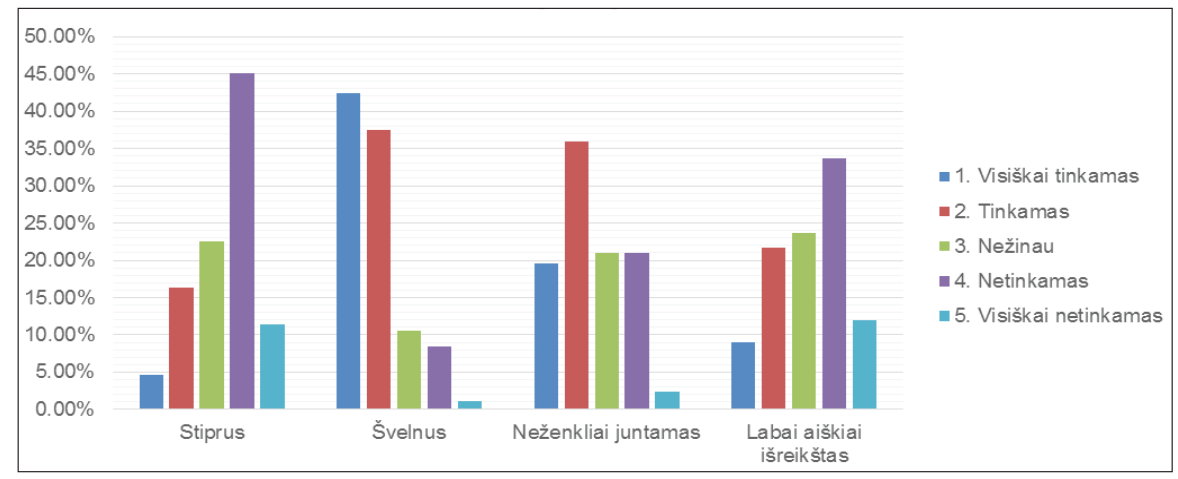

3 pav. Respondentų atsakymų pasiskirstymas pagal nuomonę dẻl kvapo intensyvumo tinkamumo (N=342). Atsakymų dalis proc.

deda siekti norimų rezultatų. Pagarba praeičiai, savo šalies ir organizacijos kultūrai formuoja mūsų tapatybę ir užtikrina esamų tradicijų tęstinumą bei naujų kūrimą.

- Bendruomeniškumas - mums yra nuolatinis procesas, kurio rezultatas ilgalaikiai ir glaudūs bendruomenès narių santykiai. Mūsų principai - bendravimas 


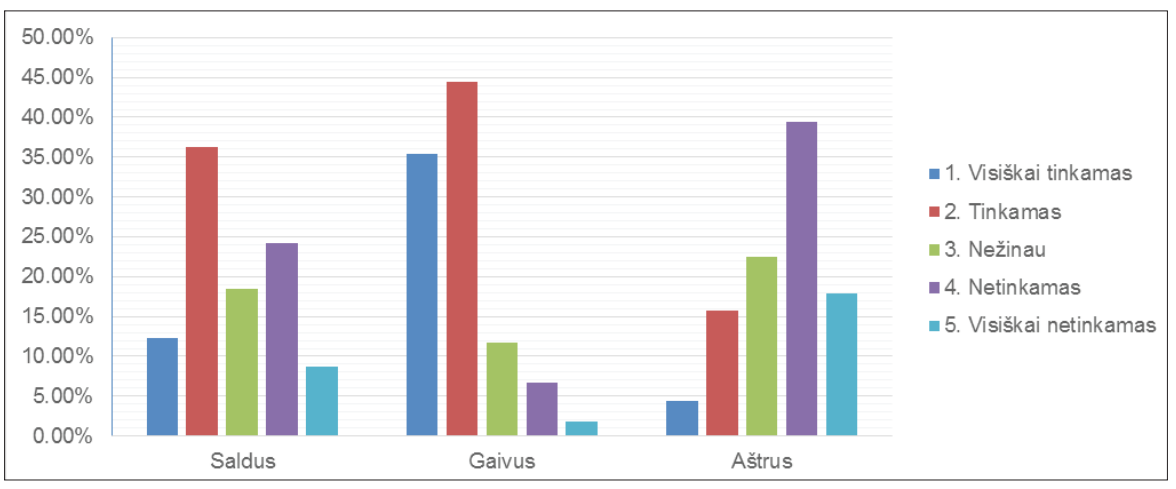

4 pav. Respondentų atsakymų pasiskirstymas ị klausimą kaip įsivaizduoja Kauno kolegijos reprezentacinị kvapą $(\mathrm{N}=342)$. Atsakymų dalis proc.

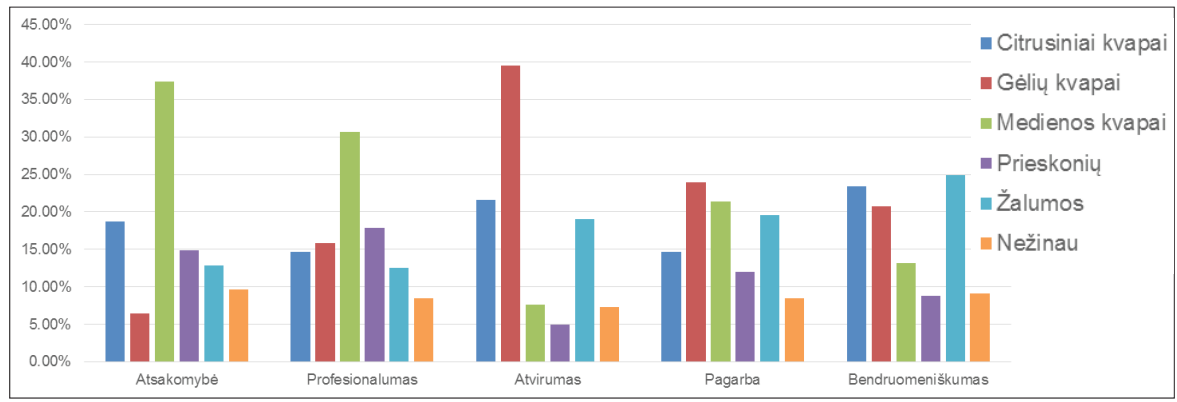

5 pav. Respondentų atsakymų pasiskirstymas pagal kvapų asociacijas susijusias su Kauno kolegijos vertybėmis $(\mathrm{N}=342)$. Atsakymų dalis proc.

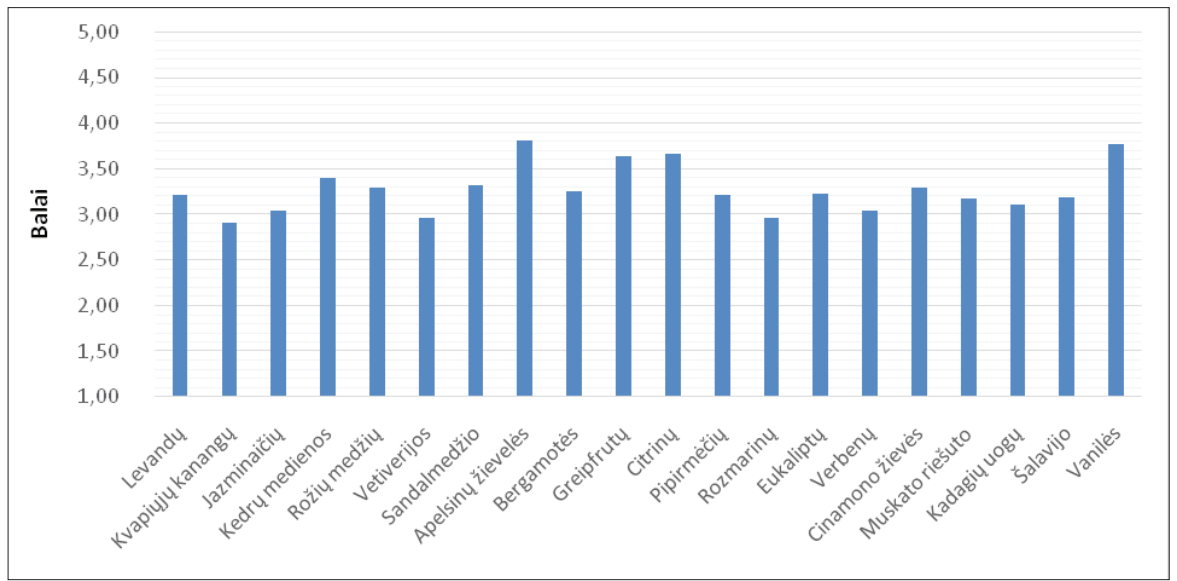

6 pav. Respondentų atsakymų dažnumo vidurkių pasiskirstymas pagal kvapų tinkamumą reprezentuoti Kauno kolegiją ( $\mathrm{N}=342)$. Atsakymų vidurkis balais.

ir bendradarbiavimas, dalijantis sukaupta patirtimi, žiniomis bei idejjomis. Kolegijos sẻkmę kuria bendrai sutelktos kiekvieno bendruomenès nario pastangos.

Atsižvelgiant ị tai buvo sudaryta dešimties klausimų anketa. Anketos struktūrą sudaro trys dalys: įžanginè, pagrindinè ir padèties. Pirmojoje dalyje pateiktas įžanginis žodis, kuriame paaiškinami tyrimo tikslai, nurodoma, kas atlieka tyrimą ir akcentuojamas konfidencialumas. Pagrindinè anketos dalis apima klausimus nagrinèjama tema. Padèties dalị sudaro klausimai apie respondentų lytị ir užimamą poziciją organizacijoje
(1 lentelè).

Gautos užpildytos anketos buvo kruopščiai patikrintos. Anketų duomenys buvo apdorojami Microsoft Office Excel programa. Tyrimo duomenų rinkimas ir jų apdorojimas kompiuterine programa buvo atliekami laikantis etikos reikalavimu.

Etniniai tyrimo principai: atliekant tyrimą buvo vadovaujamasi etikos principais: konfidencialumas - respondentai buvo informuoti, kad visi anketos duomenys pateikiami tik statistiškai apibendrinti, išsaugant apklausiamujų anonimišsumą ir konfidencialumą; informuotumas - tiriamiesiems prieš atliekant apklausą buvo suteikta informacija apie tyrimą; savanoriškumas - respondentai turèjo laisvę apsispręsti ar nori dalyvauti apklausoje. Buvo apklausiami tik tie, kurie sutiko atsakyti ị klausimus.

\section{Tyrimo rezultatai}

Tyrime dalyvavo 342 Kauno kolegijos bendruomenès nariai, iš kuriu 265 moterys ir 77 vyrai. Pagal pareigas Kauno kolegijoje tyrime dalyvavo 265 studentai, 45 administracijos darbuotojai ir 32 dèstytojai. Apklausoje dalyvavo 5 proc. Kauno kolegijos bendruomenès narių.

Apibendrinus rezultatus tyrimas parodè, kad 70 proc. $(\mathrm{N}=239)$ respondentu mano, kad reprezentacinis kvapas yra „labai svarbus“ ir „svarbus" kuriant organizacijos ịvaizdị ir tik 6 proc. $(\mathrm{N}=20)$ atsakè kategoriškai, kad kvapas yra „labai nesvarbus" ir ",nesvarbus" kuriant organizacijos ịvaizdį (1 pav.).

Didžioji dalis respondentų, turinčių teigiamą nuomonę apie reprezentacinio kvapo svarbą, taip pat mano, kad kvapas padeda kurti organizacijos ịvaizdị ir tik 


\section{6}

šiek tiek mažiau respondentų mano, jog kvapų panaudojimas padeda atskleisti institucijos identitetą, formuoja jos kultūrą bei pagerina komunikaciją su išore (2 pav.). Pojūčių marketingas yra vienas iš galimų variantų, norint formuoti teigiamą, išskirtinị organizacijos ịvaizdį [11].

Išanalizavus duomenis matyti, kad kuriant organizacijos ịvaizdị respondentai rinktųsi gaivius su citrusinių vaisių natomis kvapus. Paklausus respondentų, kaip jie issivaizduoja Kauno kolegijos kaip organizacijos reprezentacinio kvapo intensyvumą, atsakymai rodo, kad tyrimo dalyviai linkę rinktis švelnius, subtilius arba neženkliai juntamus kvapus (3 pav.).

Stiprus ir labai stiprus kvapas respondentams dažniausiai atrodo netinkamas arba visiškai netinkamas organizacijos reprezentacinio kvapo intensyvumui. Galime teigti, kad respondentai pasirinko tik žinomus ir įprastus kvapus. Tai atskleidžia respondentų nepakankamą susipažinimą su kvapų ịvairove. Tai turès ịtakos Kauno kolegijos kvapo sukūrimui.

Paklausus respondentų, koks jų mėgstamiausias kvapas, vieno labai dominuojančio pasirinkimo nebuvo, bet iš atsakymų galima matyti, kad tyrimo dalyviai mieliau renkasi gaivius (su citrusų natomis) bei saldžius kvapus. Iš 342 respondentų tik nedidelè dalis pasirinko atsakyti ị ši klausimą ir tai atskleidžia, kad respondentai nėra susimąstę apie tai (4 pav).

Tyrimo rezultatai parode, kad Kauno kolegijos veiklos bruožai: atsakomybe ir profesionalumas respondentams asocijuojasi su medienos kvapu, atvirumas ir pagarba su gèliu aromatu, o su bendruomeniškumu respondentams asocijuojasi žalumos ir citrusų kvapai (5 pav.).

Analizuojant gautus tyrimo rezultatus paaiškèjo, kad tinkami kvapai kuriant reprezentacini Kauno kolegijos kvapą tyrimo dalyviams yra apelsino žievelès, citrinų, greipfrutų (6 pav.).

Tyrimas parodè, kad respondentams, jų nuomone, labiausiai organizaciją reprezentuojantys kvapų panaudojimo būdas yra: aromatinès žvakès, aromatizatoriai ir aromatinès lazdelès.

\section{Išvados}

1. Kiekybinio tyrimo rezultatai atskleide, kad daugumos respondentu manymu, reprezentacinis kvapas yra „svarbus" kuriant organizacijos ịvaizdị. Organizacijos ịvaizdžio kūrimui respondentai rinktųsi gaivius su citrusinių vaisių natomis, švelnius, subtilius arba neženkliai juntamus kvapus.

2. Tyrimo rezultatai parodè, kad Kauno kolegijos veiklos bruožai: atsakomybe ir profesionalumas respondentams asocijuojasi su medienos kvapu, atvirumas ir pagarba su gèlių aromatu, o su bendruomeniškumu respondentams asocijuojasi žalumos ir citrusų kvapai. Respondentų manymu, tinkami įvairūs organizaciją reprezentuojantys kvapu panaudojimo būdai: aromatinès žvakès, aromatizatoriai ir aromatinès lazdelès.

\section{Literatūra}

1. Baltušienė R. İmonès įvaizdžio svarba ir jị lemiantys veiksniai. Studentų mokslinès konferencijos "Jaunasis mokslininkas" 2007 m. straipsnių rinkinys 2007;1-4. Prieiga per internetą: http://jaunasis-mokslininkas.asu.lt/smk_2007/vadyba/Baltusiene_Rasa.pdf.

2. Monkevičienė Z., Liugailaitė-Radzvickienė L. Organizacijos strategijos ir vertybių sąsaja. Ekonomika ir vadyba, 2009;14: 315-322.

3. Mikelionytė A. Organizacijų ịvaizdžio tipai ir jų lyginamosios savybès. Studentų mokslinès konferencijos "Jaunasis mokslininkas" 2007 straipsnių rinkinys. Prieiga per internetą: http://www.lzuu.lt/jaunasis_mokslininkas/smk_2007/vadyba/ Mikelionyte_Asta.pdf

4. Krishna A, Schwar N. Sensory marketing, embodiment, and grounded cognition: A review and introduction // Journal of Consumer Psychology 2014;24(2): 159 - 168.

https://doi.org/10.1016/j.jcps.2013.12.006

5. Anggie C, Haryanto J O. Analysis of the effect of olfactory, approach behavior, and experiential marketing toward purchase intention. Gadjah Mada International Journal of Business 2012; 14(1), 85-101. https://doi.org/10.22146/gamaijb.5496

6. Lietuvos Respublikos sveikatos apsaugos ministro ịsakymas Dél Lietuvos higienos normos HN 121:2010 "Kvapo koncentracijos ribinè verte gyvenamosios aplinkos ore" ir Kvapu kontrolès gyvenamosios aplinkos ore taisyklių patvirtinimo. (2010). Prieiga per internetą: https://www.etar.lt/portal/lt/ legalActEditions/TAR.2FCC47953F78

7. Mačiūnas E., Budginaitė R., Zurlytė I., Juozulynas A. Aplinkos sveikata. Medicininės atliekos. Geros praktikos vadovas. Vilnius. Valstybinis aplinkos sveikatos centras, 2009: 117-118. http://www.smlpc.lt/media/file/Skyriu info/Aplinkos sveikata/Medicininiu_atlieku_tvarkymas/Medicinines_atliekosvadovas.pdfhttp://www.vkontrole.lt/auditas_ataskaitos. php?tipas $=$ v\&metai $=2010$

9. Maymand MM, Ahmadinejad M, Nezami P. Sensory brand: studying relationship between 5 senses and brand value at world's 100 top companies. Australian Journal of Basic and Applied Sciences 2012; 6(8): 337-343.

10. Spence $\mathrm{C}$. Leading the consumer by the nose: on the commercialization of olfactory design for the food and beverage sector. Flavour. 2015:41-15. doi:10.1186/s13411-015-0041-1 https://doi.org/10.1186/s13411-015-0041-1

11. Pilelienè L. Neuromarketingo principai ir nauda organizacijos: teorinis aspektas // Management theory and studies for rural business and infrastructure Development. 2011; 5 (29):147-151.

POSSIBILITIES OF USING SCENTS, WHILE CREATING AN ORGANIZATION'S IMAGE

D.Barragan Ferrer, Ž.Mickienė, I.Kupčikienė, S.Zlatkuvienė, G.Matelienè, A.Rudžionienè, A.Šidagienè

Key words: image of the organization, sensory marketing. 
Summary

In today's competitive world, the image of the organization has become a crucial factor in acquiring a competitive advantage and developing effective business. Although there are a lot of communication channels, it is becoming more and more complex to reach the customer. New approaches to reach the customers, many organizations are opting for using sensory marketing to enhance their image - communication through the customer's senses. The different scientific literature states that positive emotions can be motivated by properly simulating the human senses. Sensory marketing could help to establish emotional relationships with clients as well as creates long-term loyalty to the organization. However, there is a lack of research in this topic, and the purpose of this study is to expose possibilities of using aromas to create the organization's image.
From the obtained results of this quantitative research revealed that, according to most of the respondents, a representative scent gives great value to the organization's image. Also, to enhance the organization's image/ company image, respondents would prefer the fresh with citrus hints, mild, delicate or lightly sensed scents. Results of this research showed that traits of Kauno Kolegija/University of Applied Sciences activities: responsibility and professionalism is associated with the scent of wood, openness, and respect with a floral aroma and community spirit with verdure and citrus scents.

Correspondence to: diana.barragan.ferrer@go.kauko.lt

Gauta 2018-09-17 